\title{
The Effect of Digital Technology Integration on Students' Academic Performance through Project-Based Learning in an E-Learning Environment
}

\author{
https://doi.org/10.3991/ijet.v16i11.19421 \\ Ahlam Mohammed Al-Abdullatif ${ }^{(凶)}$, Azza Ali Gameil \\ King Faisal University, Al Hassa, Saudi Arabia \\ aalabdullateef@kfu.edu.sa
}

\begin{abstract}
This study aimed to develop a model to examine how digital technology integration contributes to the enhancement of students' academic performance through project-based learning (PBL) amongst undergraduates in higher education. In this study, the technology acceptance model (TAM) was used as the basic model to explore the digital technology environment in terms of the perceived usefulness, perceived ease of use and attitude towards integrating digital technology and the influence of these factors on undergraduates' learning engagement and academic performance within PBL. Therefore, this study proposed a model comprising factors that assist in addressing the study objective. As the main data collection method, a questionnaire was developed to obtain relevant information regarding digital technology acceptance, PBL, students' learning engagement and academic performance. The study sample comprised 185 undergraduate students who were enrolled in a course that utilised PBL. A quantitative research method via structural equation modelling (SEM) was used to analyse the data. The finding suggested that TAM-related factors and students' learning engagement positively affect their academic performance when digital technology is integrated into the PBL environment.
\end{abstract}

Keywords - Digital technology, academic performance, project-based learning, technology integration, e-learning

\section{Introduction}

The integration of digital technology has gradually replaced traditional learning environment in educational settings. Today, numerous technological tools and applications are made available for teachers to employ in their classrooms [1]. Digital technology integration in teaching and learning has been found to be associated with enhancing the effectiveness of knowledge construction and distribution along with improving academic performance. However, if digital technology is not properly and systematically integrated into teaching and learning, its impact will not be as expected [2].

In the context of higher education, the use of digital technology forms an integral part of the contemporary student experience [3], [4]. As such, related literature has 
focused on the potential use of various digital technologies to enable, extend and even improve learning achievement and, consequently, students' overall academic performance [5]-[8]. Henderson et al. [6] studied university students' engagement with digital technologies and explored their actual experiences of digital technology use during their academic studies, highlighting students' perceptions towards important aspects of digital technology when studying and learning. They surveyed 1,658 undergraduate students, and the result of their study highlighted 11 useful characteristics of digital technologies, such as ease of organising and managing tasks, flexibilities of time and place, the ability to replay and revisit teaching materials and learning in more visual forms, to name a few.

Project-based learning (PBL) is one of the pedagogical approaches underpinned by the constructivist learning theory, which views learning as a natural process wherein meaning is constructed by students through interactions and reflections of ideas and experiences [9]. PBL is defined as 'learning that is focused on projects that engage students in investigations more specifically it allows students to learn by pursuing solutions through asking questions, debating ideas, designing plans and communicating with others' [10]. The PBL approach is advocated in the literature for its effectiveness in increasing students' motivation and engagement to learn whilst enhancing their academic performance [11]. PBL has a great educational potential to achieve meaningful learning experiences through collaborative work in the classroom as well as active involvement in the learning process social interaction and knowledge construction [12]-[14]. This dynamic interaction involves attitudes that facilitate support and the stimulation of students by both their own classmates and their teachers, which has an impact on their motivation and, ultimately, their academic performance [15].

Incorporating digital technologies in the design and implementation of PBL is widely implemented across all disciplines [16]. Blumenfeld et al. [17] argued that technology can contribute to how students find projects interesting and significant. Technology can enhance challenge, variety and choice by providing multiple levels of tasks to match student knowledge and proficiency; improve access to numerous sources of information that allow breadth in project questions; and offer many possibilities for product production. Furthermore, technology has the potential to enhance student motivation and support active learning during the various phases of the projects. Gómez-Pablos et al. [7] investigated PBL through the incorporation of digital technologies and collected data from 310 teachers regarding their opinions, and found that the majority of teachers indicated that the projects promoted active participation by students $(95 \%)$, motivated them to learn $(96 \%)$ and helped them to acquire various curricular skills (90\%). Digital technologies have undeniably made a significant contribution to the task of providing the necessary tools to optimise PBL [1]. Therefore, integrating technologies through PBL can strengthen interactivity, make collaboration smoother and facilitate tasks that are authentic and meaningfully engaging [18], [19]. Thus, incorporating digital technologies is often of great potential in the application of the PBL model.

Therefore, this study attempts to investigate what factors of digital technology integration might contribute to the enhancement of students' learning engagement and the improvement of their academic performance and how the PBL environment con- 
tributes to facilitate the process. The present study intends to contribute to the literature by examining the factors that influence students' decision to use or accept digital technology integration when learning in a PBL environment, through the technology acceptance model (TAM), and the effect of these factors on both students' learning engagement and academic performance. Therefore, this study aims to address the following main research question:

How does digital technology integration in PBL affect students learning engagement and academic performance? How are the factors of TAM (perceived ease of use, perceived usefulness, and attitudes toward integrating) contribute to this affect?

Accordingly, three sub-research questions are formulated as following:

- What is the relationship between students' perceived ease of use of digital technology integration and their learning engagement and academic performance in PBL environment?

- What is the relationship between students' perceived usefulness of digital technology integration and their learning engagement and academic performance in PBL environment?

- What is the relationship between students' attitudes toward digital technology integration and their learning engagement and academic performance in PBL environment?

\section{Literature Review and Hypotheses Development}

This study attempts to explain the conceptual model proposed in Figure 1, which presents the impact of digital technology integration in PBL on students' learning engagement and academic performance via the TAM. Digital technology integration variables (constructs) include perceived ease of use (PEU), perceived usefulness (PU), attitudes towards integration (AI), project-based learning (PBL), students' engagement (SE) and students' academic performance (AP). The variables included in the conceptual model (as shown in Figure 1) are divided into three types. Independent Variables are the influencing variables from which paths (or arrows) only come out, and these include two variables (PEU, PU). Mediator Variables are the influencing and affected variables wherein paths (arrows) either exit or enter. These include PBL, SE and AI. The Dependent Variable (AP) is affected by the independent and mediator variables and can only receive paths (arrows) that enter them.

The TAM is one of the most cited models in explaining attitudes towards technology use [20], such as integrating digital technologies. Amongst the many variables that may influence technology use, Davis [21] suggests two determinants that are especially important. The first is perceived usefulness, which is defined as 'the degree to which a person believes that using a particular system would enhance his or her job performance'. The second path is perceived ease of use, which refers to 'the degree to which a person believes that using a particular system would be free of effort' [21, $\mathrm{p}$. 320]. According to the TAM, perceived usefulness and perceived ease of use are the two major factors that influence rejection or acceptance of technology. Both have been found to positively influence respondents' attitudes towards technology use, 
which then influence their behavioural intention of using the technology [22]. Despite the fact that some researchers claimed that attitude towards usage of systems mediate the impact of perceived ease of use and perceived usefulness on behavioural intention [20], according to Davis et al. [23], perceived usefulness may directly affect behavioural intention to use technology regardless of one's attitude towards the system.

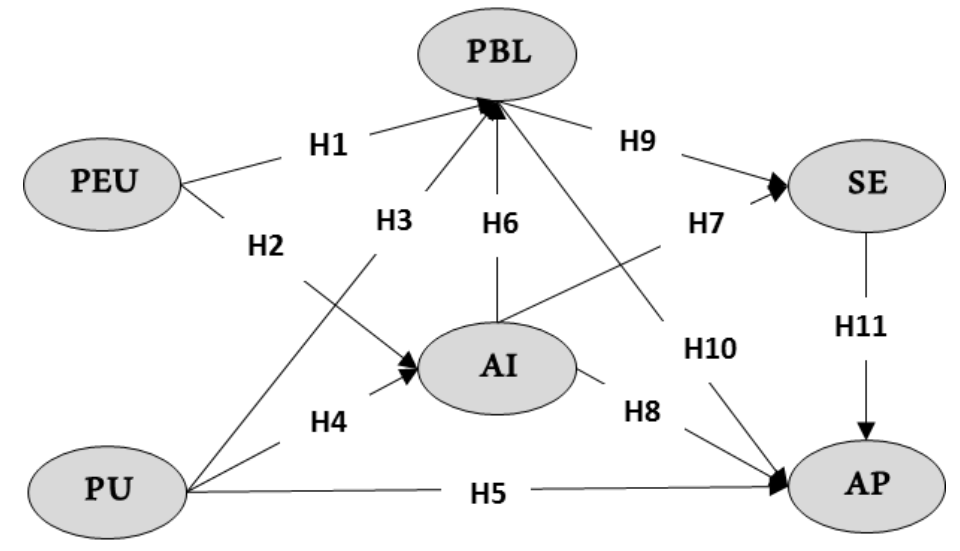

Fig. 1. Conceptual model

Considerable research has been done on the variables proposed in the theory of reasoned acceptance, which deals with users' acceptance and rejection of technology use through their perceptions of the usefulness and ease of technology use [20], [24], [25]. With the increased shift towards PBL as a learner-centred approach in the teaching and learning context and the potential of digital technology integration, the application of the PBL model entails an examination of the extent to which the factors of usefulness, ease of use and attitudes towards the integration of digital technologies through PBL contribute to the enhancement of students' learning engagement and academic performance. In this context, the TAM determines two basic factors of user acceptance of digital technology; PU and PEU as the primary factors of students' AI within PBL. In this study, the model examines these two factors that directly affect students' AI in PBL. The model also explores how these factors influence SE which, in turn, affect the AP of the students. Hence, the following hypotheses are proposed:

- H1: PEU has a positive effect on PBL

- H2: PEU has a positive effect on AI

- H3: PU has a positive effect on PBL

- H4: PU has a positive effect on AI

- H5: PU has a positive effect on AP.

Brown et al. [26] argued that when technology is meaningfully integrated into the teaching and learning environment, students' attitudes are positively influenced towards being more motivated and engaged; therefore, they move beyond knowledge and comprehension to the application and analysis of information. Attitude, which is 
defined by Weissman and Beck [27, p. 5] as individual's 'tendency to evaluate an object, or a symbol in a certain way', mostly shapes the behaviours of the students [26]. According to Karaçalli and Korur [28] students' attitudes affect both their critical thinking and their level of collaboration in learning. In the PBL approach, students' achievement increases by raising their desire to learn, that is, their attitudes towards learning [29]-[31]. Students' interests and attitudes about a particular topic or domain can greatly influence their performance, thus increasing their achievement and their motivation to continue learning in that area [28].

Research on attitudes about PBL suggest that the PBL approach is positively associated with students' interest and enjoyment of the experience of participating in authentic projects; moreover, they always find value in doing tasks associated with PBL courses [26], [30], [32]-[35]. Perrault and Albert [36] claimed that active learning through PBL may enhance certain attitudes of students, which can ultimately have an impact on their future positive and sustainable behaviours. Beier et al. [37] examined the effectiveness of PBL courses on students' attitudes, major choices and career aspirations with a relatively large sample of students who have either taken at least one PBL course and students who have not. They found that engaging in at least one PBL course during the first four semesters affected students' perceptions of their skills and of the utility value of participating in such courses. Lima et al. [38] assessed students' attitudes about PBL in an engineering course and found that, generally, PBL is positively received and taught students' skills associated with communication and project management, which they would not normally acquire in engineering courses. Furthermore, the benefits of PBL include improved attitudes toward learning and the subject matter itself [30], [31], [39]. On the basis of the above discussion, the following hypothesis are proposed:

- H6: AI has a positive effect on PBL

- H7: AI has a positive effect on SE

- H8: AI has a positive effect on AP

In the related literature, PBL has been advocated for enhancing students' interest and attitudes towards learning and their curiosity to pursue further education [40]. Through the PBL approach, students are meaningfully engaged when trying to solve a problem by searching, analysing, evaluating and synthesising knowledge [39], [41]. 'Students become more engaged in learning when they have a chance to dig into complex, challenging, and sometimes even messy problems that closely resemble real life' [42, p. 298]. One of the significant benefits of PBL is authenticity [43], which enhances students' motivation to learn, promotes critical thinking and meaningful learning and creates a self-regulated learner who is committed to complete the required learning tasks successfully [44], [45].

A vast number of empirical studies that investigated the effectiveness of PBL in higher education settings indicated a positive association with improved students' motivation, engagement, achievement and overall academic performance [10], [13], [14], [28], [40], [46]-[48]. Bilgin et al. [34] investigated the effects of the PBL method on undergraduate students' achievement and its association with their self-efficacy beliefs about science teaching and opinions about PBL. They concluded that students who studied with PBL produced better performance and expressed mostly positive 
opinions about the use of the PBL method. Meanwhile, Egilmez et al. [11] studied the use of PBL in teaching stimulation for undergraduate and graduate students and surveyed the effectiveness of PBL based on the course learning outcomes. The results indicated that the proposed PBL approach is effective in improving students' learning experience and provided critical support for achieving the intended learning outcomes. In addition, Yusof and Song [49] investigated students' engagement and utilisation of PBL in an e-learning environment through blended learning and reported students' positive response, positive engagement and better performance.

Many studies have shown that PBL is an efficient teaching strategy to enhance students' learning motivation and help them to actively engage in the learning activities [50]. Lee et al. [51] argued that PBL is a favoured pedagogical strategy for encouraging students to engage in self-determined learning whilst developing a range of skills and abilities that are integral to the profession. In summary, evidence of the potential of PBL approach, especially in terms of facilitating learning achievement and motivation of students, is well documented in prior studies [50]. Therefore, the following hypothesis are proposed:

- H9: Integrating digital technology in PBL has a positive effect on SE

- H10: Integrating digital technology in PBL has a positive effect on AP

Learning engagement, which refers to the active participation of students in their learning process [20], has been demonstrated to positively affect the learning experience quality [40]. Warnock and Duncan [52] stated that student engagement must be in centre of the learning process. In higher education learning, meaningful student engagement is achieved by providing 'experimental opportunities to empower and encourage students to devote greater time, energy' and effort towards the designed activities to enhance learning [53, p. 197]. All these aspects can be achieved in PBL as Iwamoto et al. [54] argued that PBL is an innovative approach wherein students drive their own learning through inquiry, standards alignment and collaborative research. A study by Nielsen et al. [55] to examine the effect of the PBL on students' cooperative learning and attitudes found that PBL is an effective teaching model for engineering education students. The engineering students were able to achieve process skills, they were more motivated to learn and actively engaged in the outside sources to accomplish the requirements of the project. Moreover, PBL has the potential to enhance students' motivation and attitudes, learning skills, learning engagement, academic achievement [31], [56]-[59]. Therefore, the final hypothesis is proposed as following:

- H11: SE has a positive effect on AP.

\section{Research Methods}

Current study aimed to develop a conceptual model to assess the effect of digital technology integration on students' academic performance in a PBL environment. Therefore, a quantitative approach using a survey questionnaire instrument was used. 


\subsection{Setting and sample}

The participants of the current study were female bachelor's degree students from the Faculty of Education, who were taking a compulsory course on Computers in Education (TE304). The students came from different majors, including Childhood Education, Special Needs Education, Educational Technology and Art Education, with various levels of digital technology understanding and experience. At the beginning of the semester, they were introduced to the PBL approach wherein the tasks and requirements were clearly explained to them. The PBL represented $40 \%$ of the final course assessment. To accomplish the course project successfully, students were required to work collaboratively and utilise various forms of digital technologies (e.g. animations, augmented reality, social media, mobile Apps, Blackboard, etc.) in each step of their PBL (e.g. plan, design, development and delivery of their projects). At the end of the semester, after 14 weeks of using integrated digital tools and applications, the students were invited to complete a paper-based questionnaire to reflect on their perceptions towards their experiences.

\subsection{Data collection and measurement}

Data were collected amongst eight classes of students $(n=200)$ taking the same subject (TE304). Questionnaires were distributed to 200 students, of whom 185 agreed to respond to the questionnaire; thus, the response rate was $92 \%$ of the intended population. According to Hassan [60], the appropriate sample size should not be less than the number of variables multiplied by 20 (p. 462). Since this study has six variables (PEU, PU, PBL, SE, AI, AP), the sample size of $185(6 \times 20=120<185)$ is more than sufficient for current study.

The survey questionnaire, which was administrated manually to the 185 participants, consisted of 33 items that were measured by a 5-point Likert scale ( $1=$ strongly disagree, $2=$ disagree, $3=$ undecided, $4=$ agree and $5=$ strongly agree). The collected data were entered and tabulated in SPSS v. 23. Then, in order to examine the proposed conceptual model, the structural equation modelling (SEM) method available in the LISREL8.8 programme was used. The survey questionnaire instrument featured the six constructs proposed in the conceptual framework in Figure 1. To ensure content validity, the questionnaire items were adopted from previous studies (shown in Table 1) and minor modifications were made to address the context of this study. Table 1 shows the source of all constructs in the research model along with the number of items in each construct (the questionnaire items of all constructs are shown in the Appendix). 
Table 1. Constructs in the research measurement

\begin{tabular}{|l|c|l|}
\hline \multirow{2}{*}{ Constructs } & \multicolumn{2}{|c|}{ Measures } \\
\cline { 2 - 3 } & \# of Items & \multicolumn{1}{|c|}{ Source } \\
\hline PEU & 5 & Weng et al. $[24]$ \\
\hline PU & 5 & Weng et al. [24] \\
\hline AI & 4 & Weng et al. [24] \\
\hline AP & 6 & Papaioannou [61] \\
\hline SE & 7 & Krause and Coates [62] \\
\hline PBL & 6 & Alorda et al [63] \\
\hline
\end{tabular}

\section{$4 \quad$ Data Analysis}

\subsection{Participants' demographic information}

Table 2 lists the demographic information concerning participants' gender, age and academic major. As shown in Table 2, participants were undergraduate level studying bachelor degree at the time of this research. $97.3 \%$ were between 18 and 20 years old and $2.7 \%$ were between 21 and 23 years old. Most participants specialized in Childhood Education (53\%), while 34\% of them specialized in Educational Technology. Relatively small percentage of participants were specialized in Special Needs Education $(8.1 \%)$ and Art Education $(4.3 \%)$.

Table 2. Participants demographic information

\begin{tabular}{|l|c|c|}
\hline \multicolumn{1}{|c|}{ Characteristic } & Number & \% \\
\hline Male & & 0 \\
\hline Female & 0 & 100 \\
\hline Total & 185 & 100 \\
\hline \multicolumn{1}{|c|}{ Academic Major } & 185 & 97.3 \\
\hline $18-20$ years old & 180 & 2.7 \\
\hline $21-23$ years old & 5 & 100 \\
\hline Total & 185 & 53 \\
\hline & & 34.6 \\
\hline Childhood Education & 98 & 4.3 \\
\hline Educational Technology & 64 & 8.1 \\
\hline Special Needs Education & 8 & 100 \\
\hline Art Education & 15 & \\
\hline Total & 185 & \\
\hline
\end{tabular}

\subsection{Measurement model analysis}

In analysing the data, a two-step procedure according to Hair et al. [64] were followed. First, the measurement model to measure reliability and validity was examined. Second, the structural model (SEM) was applied to investigate the direction and strength of the relationships between the theoretical model constructs. 
The reliability of the research instrument which consisting of six constructs was calculated using Cronbach's alpha coefficient in order to measure the internal consistency between the items of each construct. The result in Table 3 shows the reliability values of all six constructs (PEU, PU, PBL, SE, AI, AP) were ranging from 0.77 to 0.83 (all surpassed the cut-off-value of 0.7) [60]. The result in Table 3 also shows the composite reliability values of all the six constructs were ranging from 0.85 to 0.90 (all surpassed the cut-off-value of 0.7) [64].

Table 3. Reliability and convergent validity analysis

\begin{tabular}{|l|c|c|c|}
\hline \multicolumn{1}{|c|}{ Constructs } & Cronbach's Alpha & Composite Reliability & $\begin{array}{c}\text { Average Variance Ex- } \\
\text { tracted (AVE) }\end{array}$ \\
\hline PEU & 0.80 & 0.87 & $0.58^{*}$ \\
\hline PU & 0.83 & 0.89 & $0.61^{*}$ \\
\hline AI & 0.77 & 0.85 & $0.60^{*}$ \\
\hline AP & 0.78 & 0.88 & $0.57^{*}$ \\
\hline SE & 0.77 & 0.90 & $0.58^{*}$ \\
\hline PBL & 0.82 & 0.86 & $0.57^{*}$ \\
\hline
\end{tabular}

$*$ AVE $>0.5$

To construct validity of the measurement model, convergent validity was examined by calculating the Average Variance Extracted (AVE) from the constructs. Table 3 shows that the AVEs of all the six constructs passed the recommended value of 0.5 [64]. To verify the discriminant validity, the square root of the AVE for all constructs were calculated and used to compare with the correlations between constructs [64]. Table 4 shows that all the square roots of the AVEs are greater than the pairwise correlations involving the constructs.

Table 4. Discriminant validity

\begin{tabular}{|l|c|c|c|c|c|c|}
\hline \multicolumn{1}{|c|}{ Constructs } & PEU & PU & AI & AP & SE & PBL \\
\hline PEU & $\mathbf{0 . 7 6}$ & & & & & \\
\hline PU & 0.50 & $\mathbf{0 . 7 8}$ & & & & \\
\hline AI & 0.67 & 0.53 & $\mathbf{0 . 7 8}$ & & & \\
\hline AP & 0.58 & 0.52 & 0.66 & $\mathbf{0 . 7 5}$ & & \\
\hline SE & 0.42 & 0.30 & 0.42 & 0.52 & $\mathbf{0 . 7 6}$ & \\
\hline PBL & 0.47 & 0.35 & 0.51 & 0.57 & 0.66 & $\mathbf{0 . 7 5}$ \\
\hline
\end{tabular}

\subsection{Structural model analysis}

After the measurement model was confirmed, the SEM was implemented as the main statistical technique to analyse data. Specifically, the SEM method available in the LISREL8.8 programme was used to obtain the causal model that illustrates the effects (direct and indirect) amongst the current study theoretical constructs, which are included in the conceptual model illustrated in Figure 1. The overall goodness of fit using fit indices (X2, df, X2/df, RMR, IFI, CFI and RMSEA) were assessed. The results of the LISREL8.8 programme indicated that the SEM (causal model) in Figure 2 had good goodness of fit indicators (shown in Table 5), wherein the value of X2 
was not statistically significant, and the values of all indicators fell within the acceptable range for each indicator. This indicates a good fit of the model with the data being tested [60].

It can be seen from Table 5 that key statistics of the conceptual model were very good. Therefore, the conceptual model of this study is valid, and the result of the hypotheses should be analysed.

Table 5. Goodness of fit statistics for the causal model

\begin{tabular}{|c|c|c|c|c|}
\hline No. & Index & Value & Acceptance Range of Index & $\begin{array}{l}\text { Best Value of } \\
\text { Index [60] }\end{array}$ \\
\hline 1 & $\begin{array}{l}\text { Chi-Square } X^{2} \\
\text { df } \\
\mathrm{P}(\mathrm{Sg} .)\end{array}$ & $\begin{array}{c}6.093 \\
0.11\end{array}$ & $\mathrm{X}^{2}$ is not statistically significant & 0 \\
\hline 2 & $\mathrm{X}^{2} / \mathrm{df}$ & 2.03 & $(0)$ to $(5)$ & 0 \\
\hline 3 & Goodness of Fit Index (GFI) & 0.99 & (0) to $(1)$ & 1 \\
\hline 4 & $\begin{array}{l}\text { Adjusted Goodness of Fit Index } \\
\text { (AGFI) }\end{array}$ & 0.92 & (0) to $(1)$ & 1 \\
\hline 5 & Root Mean Square Residual (RMR) & 0.02 & $(0)$ to $(0.1)$ & 0 \\
\hline 6 & $\begin{array}{l}\text { Root Mean Square Error of Ap- } \\
\text { proximation (RMSEA) }\end{array}$ & 0.08 & (0) to $(0.1)$ & 0 \\
\hline 7 & $\begin{array}{l}\text { Expected Cross-Validation Index } \\
\text { (ECVI) for Causal Model } \\
\text { ECVI for Saturated Model }\end{array}$ & $\begin{array}{l}0.23 \\
0.23\end{array}$ & \multicolumn{2}{|c|}{$\begin{array}{l}\text { (ECVI) for Causal Model } \leq \text { ECVI for Saturated } \\
\text { Model }\end{array}$} \\
\hline 8 & Normed Fit Index (NFI) & 0.99 & (0) to $(1)$ & 1 \\
\hline 9 & Comparative Fit Index (CFI) & 1.00 & (0) to $(1)$ & 1 \\
\hline 10 & Relative Fit Index (RFI) & 0.96 & (0) to $(1)$ & 1 \\
\hline 11 & Incremental Fit Index (IFI) & 1.00 & $(0)$ to $(1)$ & 1 \\
\hline
\end{tabular}

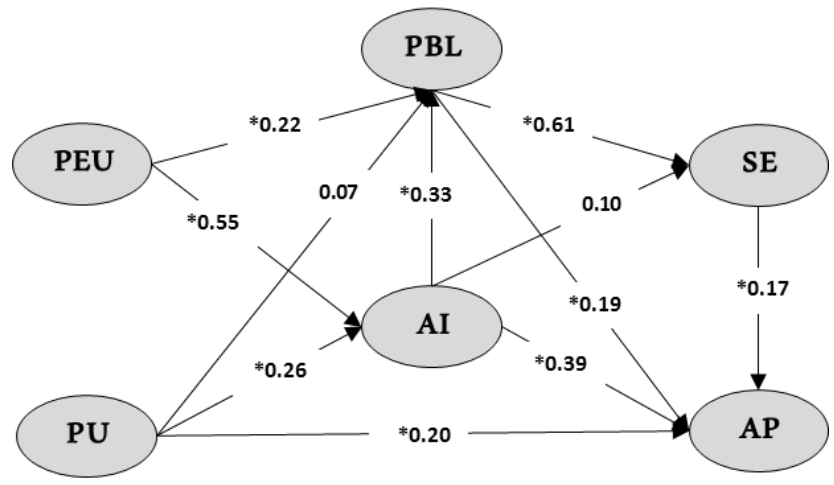

Fig. 2. Structural Equation Model (Causal Model, *asterisk represents significant paths)

\subsection{Result of hypotheses testing}

The result of previous analysis supports the conceptual framework, thus confirming the hypotheses regarding the directions and relationships between the conceptual model constructs. Table 6 shows the direct, indirect and total effects included in the 
SEM (causal model), combined with the T-values and standard errors of the effect estimate as well as the statistical significance of the effect.

Table 6. The direct, indirect and total effects included in the SEM

\begin{tabular}{|c|c|c|c|c|c|c|c|}
\hline & \multicolumn{2}{|c|}{ Kind of Effect } & \multicolumn{5}{|c|}{ Influencing Variables } \\
\hline & & & PEU & $P U$ & $\boldsymbol{A I}$ & $P B L$ & $S E$ \\
\hline \multirow{9}{*}{ PBL } & \multirow{3}{*}{ Direct } & Effect & 0.22 & 0.07 & 0.33 & & \\
\hline & & Sd. Error & 0.09 & 0.08 & 0.09 & & \\
\hline & & T Value & $2.52 *$ & 0.92 & $3.76 * *$ & & \\
\hline & \multirow{3}{*}{ Indirect } & Effect & 0.18 & 0.09 & & & \\
\hline & & Sd. Error & 0.05 & 0.03 & & & \\
\hline & & T Value & $3.48 * *$ & $2.83 * *$ & & & \\
\hline & \multirow{3}{*}{ Total } & Effect & 0.40 & 0.16 & 0.33 & & \\
\hline & & Sd. Error & 0.07 & 0.07 & 0.09 & & \\
\hline & & T Value & $5.36 * *$ & $2.08 *$ & $3.76 * *$ & & \\
\hline \multirow{9}{*}{ SE } & \multirow{3}{*}{ Direct } & Effect & & & 0.10 & 0.61 & \\
\hline & & Sd. Error & & & 0.06 & 0.06 & \\
\hline & & T Value & & & 1.60 & $9.55^{* *}$ & \\
\hline & \multirow{3}{*}{ Indirect } & Effect & 0.30 & 0.12 & 0.20 & & \\
\hline & & Sd. Error & 0.06 & 0.05 & 0.06 & & \\
\hline & & T Value & $5.29 * *$ & $2.45^{*}$ & $3.50 * *$ & & \\
\hline & \multirow{3}{*}{ Total } & Effect & 0.30 & 0.12 & 0.30 & 0.61 & \\
\hline & & Sd. Error & 0.06 & 0.05 & 0.08 & 0.06 & \\
\hline & & T Value & $5.29 * *$ & $2.45^{*}$ & $3.92 * *$ & $9.55 * *$ & \\
\hline \multirow{6}{*}{ AI } & \multirow{3}{*}{ Direct } & Effect & 0.55 & 0.26 & & & \\
\hline & & Sd. Error & 0.06 & 0.06 & & & \\
\hline & & T Value & $9.10 * *$ & $4.31 * *$ & & & \\
\hline & \multirow{3}{*}{ Total } & Effect & 0.55 & 0.26 & & & \\
\hline & & Sd. Error & 0.06 & 0.06 & & & \\
\hline & & T Value & $9.10 * *$ & $4.31 * *$ & & & \\
\hline \multirow{9}{*}{$\mathbf{A P}$} & \multirow{3}{*}{ Direct } & Effect & & 0.20 & 0.39 & 0.19 & 0.18 \\
\hline & & Sd. Error & & 0.06 & 0.06 & 0.07 & 0.07 \\
\hline & & T Value & & $3.44 * *$ & $6.07 * *$ & $2.74 * *$ & $2.66 * *$ \\
\hline & \multirow{3}{*}{ Indirect } & Effect & 0.34 & 0.15 & 0.12 & 0.11 & \\
\hline & & Sd. Error & 0.05 & 0.04 & 0.03 & 0.04 & \\
\hline & & T Value & $6.84 * *$ & $3.77 * *$ & $3.38 * *$ & $2.56^{*}$ & \\
\hline & \multirow{3}{*}{ Total } & Effect & 0.34 & 0.35 & 0.51 & 0.30 & 0.18 \\
\hline & & Sd. Error & 0.05 & 0.06 & 0.06 & 0.06 & 0.07 \\
\hline & & T Value & $6.84 * *$ & $5.52 * *$ & $7.80 * *$ & $5.11 * *$ & $2.66 * *$ \\
\hline
\end{tabular}

Sd. Error $=$ standard error of estimate * Statistically significant $(\mathrm{p}>0.05)$

If $1.96>\mathrm{T}$ Value $>2.58$ is statistically significant $(\mathrm{p}>0.05)$
If $2.58 \leq \mathrm{T}$ Value is statistically significant $(\mathrm{p}>0.01)$

Table 6 above and Figure 2 indicate statistically significant direct and indirect relationships with total positive effects $(\beta 1=0.40, \mathrm{t}=5.36, \mathrm{p}>0.01)$ between students' PEU of digital technology on the use of the PBL approach. This means that the great- 
er the students' PEU of digital technology integration, the more positive they are about learning through this approach using digital technology in both direct and indirect ways. The indirect effect of PEU on learning through the PBL approach was achieved through the mediator variable: students' attitude towards digital technology integration. This result supports H1, which states that there is a significant relationship between PEU and the integration of digital technology in PBL.

A statistically significant indirect relationship with total positive effect $(\beta 1=0.30, \mathrm{t}$ $=5.29, \mathrm{p}<0.01$ ) between students' PE of digital technology use and SE with digital technology integration in PBL. This means that students increasingly engaged with digital technology when they find that integrating this digital technology is easy to use through a PBL environment. Meanwhile, the indirect effect of PEU on SE is achieved by two mediator variables: PBL and AI. This means that students' PEU of digital technology integration has a positive effect on AI through PBL which, in turn, has a positive effect on SE.

In addition, a statistically significant indirect relationship exists with a total positive effect $(\beta 1=0.34, \mathrm{t}=6.84, \mathrm{p}>0.01)$ between students' PEU of digital technology integration and their AP. This means that the greater the students' PEU of digital technology integration, the greater their AP in an indirect way. The indirect effect of students' PEU of digital technology integration on their AP is achieved by two mediator variables: PBL and AI. There is also a statistically significant direct relationship with a total positive effect $(\beta 1=0.55, \mathrm{t}=9.10, \mathrm{p}>0.01)$ between students' PEU of digital technology on AI within the PBL environment. This means that the greater the students' PEU of digital technology use, the greater their AI in the PBL environment. Hence, $\mathrm{H} 2$ is supported.

Meanwhile, the direct effect of students' PU of digital technology integration on their learning through the PBL approach is positive but not statistically significant. In comparison, there exists a statistically significant indirect relationship with total positive effects $(\beta 1=0.09, \mathrm{t}=2.83, \mathrm{p}>0.01)$ between student's PU of digital technology integration and their learning through the PBL approach. This means that the greater the students' PU of digital technology integration, the more positive they perceived their learning through the PBL approach. Hence, H3 is supported.

In addition, a statistically significant indirect relationship with a total positive effect $(\beta 1=0.12, t=2.45, \mathrm{p}>0.05)$ exists between students' PU of digital technology integration and their SE in PBL. This means that the greater the students' PU of digital technology integration, the greater the SE in their learning through PBL. The indirect effect of PU on SE was achieved through two mediator variables: PBL and AI.

Another statistically significant direct relationship with a total positive effect $(\beta 1=$ $0.26, t=4.31, p>0.01$ ) is found between students' PU of digital technology integration and AI through PBL. This means that the greater the students' PU, the more they have a positive attitude toward digital technology integration in PBL. This provides strong support for H4. Likewise, statistically significant direct and indirect relationships with total positive effects $(\beta 1=0.12, \mathrm{t}=2.45, \mathrm{p}>0.01)$ are found between students' PU of digital technology integration and their AP through PBL environment. This means that the greater the students' PU in PBL, the greater the improvements in 
their AP in a direct way. Meanwhile, the indirect effect of PU on students' AP is achieved by two mediator variables: PBL and AI. These results support H5.

In addition, a statistically significant direct relationship with a total positive effect $(\beta 1=0.33, t=3.76, p>0.01)$ exists between students' AI and their learning through the PBL approach. This means that the greater the students' AI, the greater their perception of learning in a PBL approach. These results support H6, which states that students' AI has a positive effect on their attitudes towards learning through the PBL approach. The direct effect of AI on SE is positive but not statistically significant. However, there exists a statistically significant indirect relationship with a total positive effect $(\beta 1=0.20, t=3.50, p>0.01)$ between students' AI and SE. This means that the greater the students' AI in PBL, the greater the SE in their learning in an indirect way. The indirect effect of AI on SE is achieved by one mediator variable: PBL. Thus, H7 is supported, which posits a significant relationship between AI and SE.

There are statistically significant direct and indirect relationships with total positive effects $(\beta 1=0.51, t=7.80, p>0.01)$ between students' AI and their AP in PBL. This means that the greater the students' AI, the better their AP in a PBL environment in both direct and indirect ways. The indirect effect of AI on AP is achieved through two mediator variables: PBL and SE. Thus, H8 is supported.

A statistically significant direct relationship with a total positive effect $(\beta 1=0.61, \mathrm{t}$ $=9.55, p>0.01)$ exists between PBL and SE. This means that the more the students utilise digital technology through the PBL approach, the greater the SE in their learning in a direct way. This result supports H9, which assumes the positive effect of utilising digital technology in PBL on SE. Likewise, there are statistically significant direct and indirect relationships with total positive effects $(\beta 1=0.30, t=5.11, \mathrm{p}>$ 0.01 ) between PBL and students' AP. This means that the more the students utilise digital technology through the PBL approach, the greater the improvement in their AP in direct and indirect ways. The indirect effect of PBL on AP is achieved through one mediator variable: SE. Thus, H10, which highlights the positive and significant effect of PBL on students' AP, is supported.

Finally, a statistically significant direct relationship with total positive effects $(\beta 1=$ $0.18, \mathrm{t}=2.66, \mathrm{p}>0.01)$ exists between SE and AP. This means that the greater the SE in utilising digital technology through the PBL approach, the greater the improvements in their AP. Thus, H11, which assumes a positive and significant effect of SE on AP, is supported.

\section{Discussion}

The results highlight that the relationships between digital technology integration and PEU, PE, AI and SE help improve the academic performance of undergraduate students through a PBL environment. These results are supported by the TAM literature [21] wherein PEU and PE are the two important factors that positively or negatively influence individual behaviours towards technology - directly and indirectlythrough the influence of individuals' attitudes towards technology use. With a learnercentred approach, such as PBL, students construct their knowledge in an interactive 
and collaborative learning environment. Through various projects, students engage in investigations by asking questions, debating on ideas, designing plans and communicating with others [10, p. 46]. The useful characteristics of digital technologies offer great potential to support students' learning within a PBL environment [6]. The results of this study confirm the notion that the use of digital technology in PBL facilitates flexible and quick communication (useful), which results in an effective interaction and collaboration between students and their peers and the successful completion of their projects. Likewise, the ease of organising and managing of learning tasks (ease of use) along with the ability to access, reply and revisit materials anytime and anywhere (ease of use, usefulness) motivate students to actively participate in their learning and consequently generate a positive attitude towards learning, thereby resulting in better academic performance.

In addition, the study results support the idea that digital technology integration in PBL positively influences students' learning engagement. The results indicate that the increased use of digital technology through PBL increases students' learning engagement and, ultimately, their academic performance. Indeed, digital technology, through PBL, facilitates authentic and meaningfully engaging learning tasks [18], [19]. Digital technology can enhance challenge, variety and choice by featuring multiple levels of tasks to match students' individual knowledge and proficiency, providing access to numerous sources of information that allow breadth in project tasks and offering many possibilities to support knowledge production [17]. The result of the effect of students' engagement on their academic performance when utilising digital technology in PBL is supported by a number of studies [11], [49], [57], [59].

\section{Implications and Limitations}

Pedagogical implications of this study results suggest that digital technologies should be systematically and appropriately designed and integrated in all of the projects' stages (e.g., planning, designing, implementation and evaluation) when determining PBL for undergraduate students. That is, if digital technologies are easy to use, students are more likely to engage in meaningful learning and achieve better learning outcomes [6]. Moreover, orienting and familiarising students to the useful characteristics of the determined digital technologies and their potential influence on facilitating learning tasks and improving overall performance can increase students' motivation and their behavioural attitudes towards accepting and effectively using digital technologies in various learning practices and aspects which, in turn, would reflect positively in their academic performance. Therefore, in selecting and designing learning tasks in PBL, university instructors and course designers should carefully consider various digital technology tools and applications, which are user-friendly and can effectively and efficiently facilitate the teaching of the required learning tasks.

Given the results of this study on the importance of integrating digital technologies in PBL and their significant impact on raising the level of students' engagement and academic performance [11], [18], [19], [59], we present a number of recommendations for instructors as follows. First, if certain digital techniques are identified for 
students and are required to use in PBL, instructors must ensure that students possess the required skills in order to ensure easy usage of these digital technologies in learning. Consequently, students must be trained on how to use and maximise these digital technologies in project completion; the necessary technical support for students must be provided if needed. Second, instructors should consider providing flexibility for students in selecting alternatives to digital technologies from those determined by the course instructor. Such flexibility will allow them to determine which technologies they find easier to use or are more useful in accomplishing the project tasks. This ensures that the students can have better learning engagement and optimal academic performance in a PBL environment.

Certain limitations should be considered when interpreting the results. First, the study was conducting within a limited setting of female students from a particular collage (Education Collage) taking the same course (Educational Technology). The situation in other contexts might reveal different results. Therefore, future research should examine the robustness of the findings across different settings (e.g., male and female students from different colleges). Second, the result of this study was based on a conceptual model of TAM-related factors. Future research should consider the extended TAM model and examine external factors such as student's technological competency and teacher support that might contribute to the conceptual space of digital technology integration and PBL environment.

\section{Conclusion}

The purpose of this study was to investigate what factors of digital technology integration contribute to the enhancement of students' learning engagement and the improvement of their academic performance and how a PBL environment contributes to facilitate this process. Therefore, a conceptual model, which consists of six constructs, PEU, PU, AI, PBL, SE and AP, was proposed and examined. We hypothesised that students, through the PBL approach, will accept and become more motivated to use digital technologies, which are perceived as easy to use and useful, so that they can successfully accomplish their learning tasks. We also proposed that students will be more meaningfully engaged in the PBL approach if they utilised digital technology that are easy to use and useful for their learning. These interrelated relationships contribute positively to enhancing students' academic performance. The results highlight that the relationships between digital technology integration and perceived ease of use, perceived usefulness, attitude towards integration and students' engagement, help improve the academic performance of undergraduate students through a PBL environment.

\section{Acknowledgement}

This research was supported by the Deanship of Scientific Research at King Faisal University [grant number 216039]. 


\section{$9 \quad$ References}

[1] Brengarth, L. B., \& Mujkic, E. (2016). WEB 2.0: How social media applications leverage nonprofit responses during a wildfire crisis. Computers in Human Behavior, 54, 589-596. https://doi.org/10.1016/j.chb.2015.07.010

[2] Rahman, A. A., Zaid, N. M., Abdullah, Z., Mohamed, H., \& Aris, B. (2015, May). Emerging project-based learning in flipped classroom: Technology used to increase students' engagement. In 2015 3rd International Conference on Information and Communication Technology (ICoICT) (pp. 212-215). IEEE. https://doi.org/10.1109/icoict. $\underline{2015.7231424}$

[3] Selwyn, N. 2014. Digital Technology and the Contemporary University. London: Routledge. Stokoe, E., B. Benwell, and F. Attenborough. 2013. University Students Managing Engagement, Preparation, Knowledge and Achievement. Learning, Culture and Social Interaction, 2(2), 75-90. https://doi.org/10.1016/j.lcsi.2013.01.001

[4] Al-Abdullatif, A., \& Gameil, A. (2020). Exploring Students' Knowledge and Practice of Digital Citizenship in Higher Education. International Journal of Emerging Technologies in Learning (iJET), 15(19), 122-142. https://doi.org/10.3991/ijet.v15i19.15611

[5] Wright, F., White, D., Hirst, T., \& Cann, A. (2014). Visitors and residents. Learning, Media and Technology, 39(1), 126-41. https://doi.org/10.1080/17439884.2013.777077

[6] Henderson, M., Selwyn, N., Finger, G., \& Aston, R. (2015). Students' everyday engagement with digital technology in university: exploring patterns of use and 'usefulness'. Journal of Higher Education Policy and Management, 37(3), 308-319. https://doi.org/10. 1080/1360080x.2015.1034424

[7] Gómez-Pablos, V. B., del Pozo, M. M., \& Muñoz-Repiso, A. G. V. (2017). Project-based learning (PBL) through the incorporation of digital technologies: An evaluation based on the experience of serving teachers. Computers in Human Behavior, 68, 501-512. https:// doi.org/10.1016/j.chb.2016.11.056

[8] Liu, Z. J., Tretyakova, N., Fedorov, V., \& Kharakhordina, M. (2020). Digital Literacy and Digital Didactics as the Basis for New Learning Models Development. International Journal of Emerging Technologies in Learning (iJET), 15(14), 4-18. https://doi.org/10.3991 lijet.v15i14.14669

[9] Dewey, J. (1938). Experience and Education. New York, NY: Collier Books.

[10] Choi, J., Lee, J. H., \& Kim, B. (2019). How does learner-centered education affect teacher self-efficacy? The case of project-based learning in Korea. Teaching and Teacher Education, 85, 45-57. https://doi.org/10.1016/j.tate.2019.05.005

[11] Egilmez, G., Sormaz, D., \& Gedik, R. (2018). A project-based learning approach in teaching simulation to undergraduate and graduate students. Paper presented at 2018 ASEE Annual Conference \& Exposition, Salt Lake City, Utah. https://peer.asee.org/ 29716. https://doi.org/10.18260/1-2--29716

[12] Raes, A., Schellens, T., De Wever, B., \& Benoit, D. F. (2016). Promoting metacognitive regulation through collaborative problem solving on the web: When scripting does not work. Computers in Human Behavior, 58, 325-342. https://doi.org/10.1016/j.chb.2015.12. $\underline{064}$

[13] Al-Balushi, S. M., \& Al-Aamri, S. S. (2014). The effect of environmental science projects on students' environmental knowledge and science attitudes. International Research in 
Geographical and Environmental Education, 23(3), 213-227. https://doi.org/10.1080/103 $\underline{82046.2014 .927167}$

[14] Kokotsaki, D., Menzies, V., \& Wiggins, A. (2016). Project-based learning: A review of the literature. Improving Schools, 19(3), 267-277. https://doi.org/10.1177/1365480216659733

[15] Johnson, D. W., \& Johnson, F. P. (1991). Joining together: Group Theory and Group Skills. Boston: Allyn \& Bacon.

[16] Isa, M., \& Kamin, Y. (2019). Effective Strategies for Integrating Project Based Learning into Woodwork Technology Education and Understanding at Tertiary Institutes in Nigeria. International Journal of Emerging Technologies in Learning (iJET), 14(20), 120-136. https://doi.org/10.3991/ijet.v14i20.11468

[17] Blumenfeld, P. C., Soloway, E., Marx, R. W., Krajcik, J. S., Guzdial, M., \& Palincsar, A. (1991). Motivating project-based learning: Sustaining the doing, supporting the learning. Educational Psychologist, 26(3-4), 369-398. https://doi.org/10.1080/00461520.1991.9653 $\underline{139}$

[18] García-Valcárcel, A. (2015). Proyectos de trabajo colaborativo con TIC. Sntesis, Madrid.

[19] García-Valcárcel, A., \& Gómez-Pablos, V. B. (2015). Evaluación de una experiencia de aprendizaje colaborativo con TIC desarrollada en un centro de Educación Primaria. Edutec, 51, 1-12. https://doi.org/10.21556/edutec.2015.51.200

[20] Al-Rahmi, W. M., Othman, M. S., \& Yusuf, L. M. (2015). Effect of engagement and collaborative learning on satisfaction through the use of social media on Malaysian higher education. Research Journal of Applied Sciences, Engineering and Technology, 9(12), 11321142. https://doi.org/10.19026/rjaset.9.2608

[21] Davis, F. D. (1989). Perceived usefulness, perceived ease of use, and user acceptance of information technology. MIS quarterly, 319-340. https://doi.org/10.2307/249008

[22] Doll, W. J., \& Torkzadeh, G. (1998). Developing a multidimensional measure of systemuse in an organizational context. Information \& Management, 33(4), 171-85. https://doi.org/10.1016/s0378-7206(98)00028-7

[23] Davis, F. D., Bagozzi, R. P., \& Warshaw, P. R. (1989). User acceptance of computer technology: a comparison of two theoretical models. Management Science, 35(8), 982-1003. https://doi.org/10.1287/mnsc.35.8.982

[24] Weng, F., Yang, R. J., Ho, H. J., \& Su, H. M. (2018). A TAM-based study of the attitude towards use intention of multimedia among school teachers. Applied System Innovation, 1(3), 36. https://doi.org/10.3390/asi1030036

[25] Aljaloud, A., Billingsley, W., \& Kwan, P. (2019). Factors that influence teachers' decisions to use smartphone clicker apps to enhance teacher-student interactions in university classrooms in Saudi Arabia. Learning: Research and Practice, 5(1), 67-86. https://doi.org/ $\underline{10.1080 / 23735082.2018 .1459802}$

[26] Brown, S. W., Lawless, K. A., \& Boyer, M. A. (2013). Promoting positive academic dispositions using a web-based PBL environment: The GlobalEd 2 Project. Interdisciplinary Journal of Problem-based Learning, 7(1), 7. https://doi.org/10.7771/1541-5015.1389

[27] Weissman, A. N., \& Beck, A. T. (1978). Development and validation of the Dysfunctional Attitude Scale: A preliminary investigation. Retrieved from https://files.eric.ed.gov/fullte $\underline{\mathrm{xt} / \mathrm{ED} 167619 . \mathrm{pdf}}$

[28] Karaçalli, S., \& Korur, F. (2014). The effects of project-based learning on students' academic achievement, attitude, and retention of knowledge: The subject of "electricity in our 
lives". School Science and Mathematics, 114(5), 224-235. https://doi.org/10.1111/ssm.12 $\underline{071}$

[29] Mioduser, D., \& Betzer, N. (2008). The contribution of Project-based-learning to highachievers' acquisition of technological knowledge and skills. International Journal of technology and design education, 18(1), 59-77. https://doi.org/10.1007/s10798-006-9010$\underline{4}$

[30] Tseng, K. H., Chang, C. C., Lou, S. J., \& Chen, W. P. (2013). Attitudes towards science, technology, engineering and mathematics (STEM) in a project-based learning (PjBL) environment. International Journal of Technology and Design Education, 23(1), 87-102. https://doi.org/10.1007/s10798-011-9160-x

[31] Ghimire, S. R., \& Bhandary, S. (2014). Students' perception and preference of problem based learning during introductory course of a Nepalese medical school. Journal of Patan Academy of Health Sciences, 1(1), 64-68. https://doi.org/10.3126/jpahs.v1i1.13024

[32] Havenga, H. M. (2015). Project-based learning in higher education: exploring programming students' development towards self-directedness. South African Journal of Higher Education, 29(4), 135-157. https://doi.org/10.20853/29-4-515

[33] Sababha, B. H., Alqudah, Y. A., Abualbasal, A., \& AlQaralleh, E. A. (2016). Project-based learning to enhance teaching embedded systems. Eurasia Journal of Mathematics, Science \& Technology Education, 12(9), 2575-2585. https://doi.org/10.12973/eurasia.2016.1267a

[34] Bilgin, I., Karakuyu, Y., \& Ay, Y. (2015). The effects of project-based learning on undergraduate students' achievement and self-efficacy beliefs towards science teaching. Eurasia Journal of Mathematics, Science \& Technology Education, 11(3), 469-477. https://doi. org/10.12973/eurasia.2014.1015a

[35] Holmes, V. L., \& Hwang, Y. (2016). Exploring the effects of project-based learning in secondary mathematics education. The Journal of Educational Research, 109(5), 449-463. https://doi.org/10.1080/00220671.2014.979911

[36] Perrault, E. K., \& Albert, C. A. (2018). Utilizing project-based learning to increase sustainability attitudes among students. Applied Environmental Education \& Communication, 17(2), 96-105. https://doi.org/10.1080/1533015x.2017.1366882

[37] Beier, M. E., Kim, M. H., Saterbak, A., Leautaud, V., Bishnoi, S., \& Gilberto, J. M. (2019). The effect of authentic project-based learning on attitudes and career aspirations in STEM. Journal of Research in Science Teaching, 56(1), 3-23. https://doi.org/10.1002 Itea. 21465

[38] Lima, R. M., Mesquita, D., \& Flores, M. A. (2014). Project approaches in interaction with industry for the development of professional competences. http://hdl.handle.net/1822/3108

[39] Chen, C. H., \& Yang, Y. C. (2019). Revisiting the effects of project-based learning on students' academic achievement: A meta-analysis investigating moderators. Educational Research Review, 26, 71-81. https://doi.org/10.1016/j.edurev.2018.11.001

[40] Korkmaz, Ö. (2018). The Effect of Project-Based Cooperative Studio Studies on the Basic Electronics Skills of Students' Cooperative Learning and Their Attitudes. Online Submission, 10(5), 1-8.

[41] Lenz, B., Wells, J., \& Kingston, S. (2015). Transforming schools using project-based learning, performance assessment, and common core standards. San Francisco, CA: John Wiley \& Sons. 
[42] Zafirov, C. (2013). New challenges for the project-based learning in the digital age. Trakia Journal of Sciences, 11(3), 298-302.

[43] Mohamadi, Z. (2018). Comparative effect of project-based learning and electronic projectbased learning on the development and sustained development of English idiom knowledge. Journal of Computing in Higher Education, 30(2), 363-385. https://doi.org/10.1007/s12528-018-9169-1

[44] Bell, S. (2010). Project-based learning for the 21st century: Skills for the future. The Clearing House, 83(2), 39-43. https://doi.org/10.1080/00098650903505415

[45] Krajcik, J. S., \& Czerniak, C. M. (2014). Teaching science in elementary and middle school: A project-based approach. New Yourk, NY: Routledge. https://doi.org/10.4324/9 $\underline{781315205014}$

[46] Ruikar, K., \& Demian, P. (2013). Podcasting to engage industry in project-based learning. International Journal of Engineering Education, 29, 1410-1419.

[47] Fernandes, S., Mesquita, D., Flores, M. A., \& Lima, R. M. (2014). Engaging students in learning: Findings from a study of project-led education. European Journal of Engineering Education, 39, 55-67. https://doi.org/10.1080/03043797.2013.833170

[48] Gibbes, M., \& Carson, L. (2014). Project-based language learning: An activity theory analysis. Innovation in Language Learning and Teaching, 8, 171-189. https://doi.org/10. $\underline{1080 / 17501229.2013 .793689}$

[49] Yusof, A. M., \& Song, H. (2010). E-project based learning using animation in primary schools. In EDULEARN10 Conference, Barcelona, Spain, July (pp. 3-8)

[50] Chiang, C. L., \& Lee, H. (2016). The effect of project-based learning on learning motivation and problem-solving ability of vocational high school students. International Journal of Information and Education Technology, 6(9), 709-712. https://doi.org/10.7763/ ijiet.2016.v6.779

[51] Lee, M. J., Nikolic, S., Vial, P. J., Ritz, C. H., Li, W., \& Goldfinch, T. (2016). Enhancing project-based learning through student and industry engagement in a video-augmented 3-D virtual trade fair. IEEE Transactions on Education, 59(4), 290-298. https://doi.org/10. $\underline{1109 / \text { te. } 2016.2546230}$

[52] Warnock, C., \& Duncan, J. (2019). Project-based learning in initial teacher training curricula: Incorporating a visual method to enhance student agency and reflexive engagement in the learning process. Journal of the European Teacher Education Network, 14, 64-75.

[53] Bovill, C., Bulley, C. J., \& Morss, K. (2011). Engaging and empowering first-year students through curriculum design: perspectives from the literature. Teaching in Higher Education, 16(2), 197-209. https://doi.org/10.1080/13562517.2010.515024

[54] Iwamoto, D. H., Hargis, J., \& Vuong, K. (2016). The effect of project-based learning on student performance: An action research study. International Journal for the Scholarship of Technology Enhanced Learning, 1(1), 24-42.

[55] Nielsen, J. D., Du, X. Y., \& Kolmos, A. (2010). Innovative application of a new PBL model to interdisciplinary and intercultural projects. International Journal of Electrical Engineering Education, 47(2), 174-188. https://doi.org/10.7227/ijeee.47.2.7

[56] Kanter, D. E. (2010). Doing the project and learning the content: Designing project-based science curricula for meaningful understanding. Science Education, 94(3), 525-551. https://doi.org/10.1002/sce.20381 
[57] Chang, C. C., \& Tseng, K. H. (2011). Using a web-based portfolio assessment system to elevate project-based learning performances. Interactive Learning Environments, 19(3), 211-230. https://doi.org/10.1080/10494820902809063

[58] Parsons, J., \& Taylor, L. (2011). Improving student engagement. Current Issues in Education, 14(1),1-33.

[59] Hung, C. M., Hwang, G.J., \& Huang, I. (2012). A project-based digital story telling approach for improving students' learning motivation, problem-solving competence and learning achievement. Journal of Educational Technology \& Society, 15(4), 368-379.

[60] Hassan, E., A. (2016). Advanced Statistics for Educational, Psychological and Social Sciences. Cairo: DarAl-FikrAl-Arabi.

[61] Papaioannou, A. (1994). Development of a questionnaire to measure achievement orientations in physical education. Research Quarterly for Exercise and Sport, 65(1),11-20. https://doi.org/10.1080/02701367.1994.10762203

[62] Krause, K.L., \& Coates, H. (2008). Students' engagement in firstyear university. Assessment \& Evaluation in Higher Education, 33(5), 493-505. https://doi.org/10.1080/02 602930701698892

[63] Alorda, B., Verd, J., Canals, V., Suenaga, K., \& Martinez, V. (2012, April). Multi-subject Project Based Learning initiative. In Proceedings of the 2012 IEEE Global Engineering Education Conference (EDUCON) (pp.1-7). IEEE.

[64] Hair, J.F., Black, W.C., Babin, B.J., Anderson, R.E., \& Tatham, R.L. (1998). Multivariate data analysis. 5thEd. Upper Saddle River, NJ: Prentice Hall.

\section{Authors}

Ahlam Mohammed Al-Abdullatif is an assistant professor in educational technology at King Faisal University in Saudi Arabia. Al-Abdullatif's research interest is in the area of e-Learning particularly on how Information and Communication Technology (ICT) enhances teaching and learning practices. She is an active professor and researcher, who published a number of research articles with well-known publishers such as Taylor and Francis, Springer andIEEE. Al-Abdullatif won the 2017/2018 Faculty Excellence Award at King Faisal University and the 2017/2018 E-learning Excellence Award from the National Centre of E-learning in Saudi Arabia.

Azza Ali Gameil is an assistant professor in educational technology at King Faisal University, Saudi Arabia. She is an active professor and researcher. Gameil's research interest focuses on technological innovations and the use of digital technologies in education along with instructional design.

Article submitted 2020-10-24. Resubmitted 2021-02-22. Final acceptance 2021-02-22. Final version published as submitted by the authors. 


\section{Appendix}

\section{Questionnaire Items}

\section{Perceived Ease of Use}

1. I find it easy to integrate digital technologies in PBL in my class.

2. Integrating digital technologies in PBL is easy and understandable.

3. My interaction with digital technologies in PBL is easy and flexible.

4. I find it easy to learn through integrating digital technologies in PBL.

5. It is easy to become skillful in integrating digital technologies in PBL.

\section{Perceived Usefulness}

1. Integrating digital technologies in PBL in my class enables me to accomplish tasks effectively.

2. Integrating digital technologies in PBL in my class improves the learning performance.

3. Integrating digital technologies in PBL increases my productivity.

4. Integrating digital technologies in PBL makes it easier for me to learn.

5. Integrating digital technologies in PBL is useful for my learning.

\section{Attitude toward Integrating}

1. Integrating digital technologies in PBL has a positive influence in learning.

2. Integrating digital technologies in PBL makes learning more interesting.

3. Integrating digital technologies in PBL is fun.

4. I like learning with integrating digital technologies in PBL.

\section{Academic Performance}

1. Integrating digital technologies in PBL helps me to learn by myself.

2. Integrating digital technologies in PBL helps me to improve my technological skills.

3. Integrating digital technologies in PBL helps me to design effective learning content.

4. I feel very satisfied when I learn new knowledge and skills in PBL through integrating digital technologies.

5. I enjoy trying my best to learn skills through integrating digital technologies in PBL.

6. What I learn through Integrating digital technologies in PBL makes me want to practice more. 


\section{Students' Engagement}

1. Integrating digital technologies in PBL makes me go through my project and make sure that it is right.

2. Integrating digital technologies in PBL makes me try to understand my mistakes when I get something wrong.

3. Integrating digital technologies in PBL makes me put more effort into learning.

4. Integrating digital technologies in PBL makes me keep trying even if something is hard.

5. Integrating digital technologies in PBL makes me look forward to finish my project successfully.

6. Integrating digital technologies in PBL makes me feel excited when I am doing my project.

7. Integrating digital technologies in PBL makes me try to work with others who can help me.

\section{Project Based Learning (PBL)}

1. Integrating digital technologies in PBL increases the motivation for the subject.

2. Integrating digital technologies in PBL is important for interaction with other groups.

3. Integrating digital technologies in PBL contributes to accomplish the course goals.

4. Integrating digital technologies in PBL makes it very important to accomplish the project tasks.

5. Integrating digital technologies in PBL helps in developing the learning process.

6. Integrating digital technologies in PBL increases my motivation towards collaboration. 